\title{
IDENTITY POSITIONS AND HALAL COSMETICS IN INDONESIAN MIDDLE-CLASS MUSLIM WOMEN
}

\author{
Abhirama SD Perdana \\ Communication Studies, School of Humanities, President University \\ E-mail: perdana.abhirama@president.ac.id
}

\begin{abstract}
Creations can become meaningful when there are audience who pay attention towards the products, enjoy and show their appreciation or even evaluation towards them. The meaning produced within a media is considered incomplete without the understanding of the audience and the meaning the audience produces in appreciating as well as responding to the media text. To understand more on the meaning of text media, therefore, it is paramount to consider and gain a thorough understanding of the meaning produced by the media audience through studying the way the audience reads, uses, and responds to the media. Utilizing Hall's Cultural Studies of dominant and oppositional readings, this paper endeavours to showcase the understanding of audience and how meaning is constructed. Locating the issue of audience research in the context of Halal Cosmetics and the Middle-Class Muslims in Indonesia, a brief overview on the theories of audience is outlined and relevant theories to the case of integrating advertisement in Indonesian cinema is employed.
\end{abstract}

Keywords: audience, audience research, middle-class Muslims

ABSTRAK. Hasil karya dapat menjadi bermakna karena adanya audiens yang memperhatikan karyam menikmati dan menunjukkan penghargaan serta evaluasi mereka terhadap karya tersebut. Makna yang diproduksi dalam pesan suatu media dianggap belum lengkap tanpa adanya pemahaman audiens dan makna yang dibuat oleh audiens dalam menghargai dan menanggapi suatu teks media. Untuk lebih memahami makna suatu teks media, sungguh penting untuk mempertimbangkan dan mengambil pemahaman penuh akan makna yang dibuat oleh audiens media lewat mempelajari cara audiens membaca, menggunakan, dan merespon suatu media. Dengan memanfaatkan Kajian Budaya yang diajukan Hall terhadap pembacaan dominan dan berlawanan, artikel ini bertujuan untuk menunjukkan pemahaman audiens dan bagaimana makna dapat dikonstruksi oleh mereka. Dengan menempatkan isu penelitian audiens ke dalam konteks Kosmetik Halal dan Muslim kalangan kelas menengah di Indonesia, suatu pembahasan singkat mengenai teori-teori audiens disajikan, serta teori-teori terkait dengan isu periklanan terintegrasi dalam sinema Indonesia digunakan di dalam artikel ini.

Kata kunci: audiens, penelitian audiens, Perempuan Muslim kalangan kelas menengah

The appreciative smile, the chuckle, the soundless mirth, so important to the success of comedy, cannot be understood unless one sits among the audience and feels the warmth created by the quality of laughter that the audience takes home with it.

\section{-- James Thurber}

You've got a song you're singing from your gut, you want that audience to feel it in their gut. And you've got to make them think that you're one of them sitting out there with them too. They've got to be able to relate to what you're doing.

-- Johnny Cash

\section{Introduction}

Early morning, I wake up, grab my tablet, and access my Facebook account to have a quick look at my favorite news media links. From the time I get up until that of when I go back to sleep, at the instances where I am exposed to a media text, I become a part of audiences. Whether the media take the form of a morning radio, newspaper stories, television programs, or the junk mails in our mailbox, we are either consciously or unconsciously exposed to these texts within the media.

The two excerpts at the beginning of the paper, by James Thurber - a Cartoonist - and Johnny Cash the famous singer - suggest the importance of the audience for their created texts (i.e. the cartoons or the songs). It can be inferred that their creations can only become meaningful when there are audience who pay attention towards the products, enjoy and show their appreciation or even evaluation towards them. It is suggested that the meaning produced within a media is still incomplete without the understanding of the audience and the meaning the audience produces in appreciating as well as responding to the media text (Croteau \& Hoynes, 2003, p.266; Macdonald, 2003, p. 23). Therefore, to understand more on the meaning of text media, it is paramount to consider and gain a thorough understanding of the meaning produced by the media audience through studying "... how people 'read', use and respond to the media (Kitzinger, 2004, p.167)." It is also 
concurred by O'Shaughnessy and Stadler (2012) who argue that "[audience] research is a crucial part of media studies, as it completes the circle of text, production, and consumption (p.97)."

Utilizing Hall's (cited in Hodkinson, 2011, pp.9293) Cultural Studies of dominant and oppositional readings, this paper endeavours to showcase the understanding of audience and how meaning is constructed. Locating the issue of audience research in the context of Halal Cosmetics and the Middle-Class Muslims in Indonesia, I first outline a brief overview on the theories of audience and employ the relevant theories to the case of integrating advertisement in Indonesian cinema.

\section{From Passive to Active Audience}

As this paper is looking at the audience as consumers of advertised product, I consider it appropriate to use the ways of looking at the audience offered by O'Shaughnessy and Stadler (2012, p.97) as both the inscribed reader - the ideal, preferred audience targeted by the text producers - and the actual reader - the audience who interpret the meaning of the advertisement. I will approach the case example using the fourth rubric in the spheres of concern audience research, by questioning about Culture, Politics, and Identity (Kitzinger, 2004, pp.169-170).

There are many alternatives of audience theories that are available to gain more insight on how the audience constructs meaning out of text media. However, at the beginning of the emergence of media studies, the widely received theory of audience was the "direct effect" - commonly known as "the hypodermic model" or the "magic bullet theory of communication" - where the audience was only deemed as those who passively received and influenced by the values, beliefs, and thought carried out by the media that was meant to possibly change the opinions of the audience (Kitzinger, 2004, p.170; O'Shaughnessy \& Stadler, 2012, p.99). This theory was challenged and criticized due to its view that the media had considerable power to influence the audiences and that the audiences was passively brainwashed to follow the bidding of the media without the audiences being able to question what they can do with the media (Kitzinger, 2004, p.170). Despite the criticism, the current days can still witness the examples of this hypodermic model through product advertisements. In these advertisements, the producers make efforts to influence the advertisement audience to know and use their products. However, the differences between the past and current audiences lay in the current's ability of having and practicing audience “... autonomy and demassification;" where the audience have the choice of whether conforming to the influence of the media and whether even willing to pay attention to the media (Sayre \& King, 2010, pp.51-52).

As the current audience are not powerless in choosing their positions when exposed to certain media, Croteau and Hoynes (2003, p.266) concur that audiences are active in constructing their own interpretation of meaning and merely following the meaning intended and produced by the media. This shift of viewing the audiences from a Passive to Active Audience was triggered by Hall's and Morley's (cited in Hodkinson, 2011, pp.92-95; Kitzinger, 2004, pp.170-172; O'Shaughnessy \& Stadler, 2012, pp.102-103) theory of Encoding, Decoding, and Preferred Meaning. They argue that the Encoding-Decoding theory emphasizes on the interplay

... between the media
message, as it is constructed or
'encoded' by a media
producer, and the ways that
the message is interpreted or
'decoded' by audiences...
[However], a particular
decoding does not necessarily
follow from a specific encoded
meaning (cited in Croteau \&
Hoynes, 2003, p.275-276).

In their consecutive studies, a model that suggests for the different interpretations and responses of the audience are developed and located in three categories of readings/positions: namely, 1) preferred/dominant hegemonic - where the audience willingly accept the influence of the media; 2) negotiated - the audiences negotiate with the preferred response towards the media, but they may only accept and reject parts of the intended meaning; and 3) oppositional - where the audiences are completely against the preferred response towards the media (cited in Hodkinson, 2011, p.93; O'Shaughnessy \& Stadler, 2012, p.102).

The following section looks into the selected context of the growing population of Indonesian Middle-Class Muslims and their preference of beauty products. The theory in light of the Active Audience paradigm is used to the context as means to assess the different positions of Indonesian Middle-Class Muslims in making their choice of using Halal Cosmetics.

\section{The Middle-Class in Indonesia and Beauty Products}

According to a report of Asian Development Bank (cited in Tajudin, Kurniawan, \& Hidayat, 2014, p.43) covered in the Special Report of MiddleClass Muslim in Tempo Magazine English Edition, there has been an increasing trend in the population of the Indonesian Middle-Class - a social group 
whose daily spending ranges from USD 2.50 to 25.00 - reaching up to an estimate of 130 million Indonesians with a predicted increase of eight to nine more million persons per year. Tajudin et al. (2014, p.43) further content that since the number of the Middle-Class is sixty percent of the whole population of Indonesia, a country of Muslim majority, then it can be inferred that the social group is dominated by the Muslims. Still according to the Special Report, a number of business industries is eager to meet the needs this large market of Middle-Class Muslims, which is claimed to expect for consuming products that are not only high-quality but also that conform to the Halal (religiously permissible) requirement for Muslims (Tajudin et al., 2014, p.43). Therefore, there is prospect of viewing the audience as a market; namely as consumers that may likely purchase a certain product (Grossberg, Wartella, Whitney, \& Wise, 2006, p.224).

One of the prospective industries to offer to this market of Middle-Class Muslims is the beauty products, especially cosmetics. The Ministry of Trade, Republic of Indonesia (cited in Global Business Guide Indonesia, 2014), reports that since 2011 there has been a steady increase in the Indonesian sales of cosmetics - marked by the $15 \%$ increase from more than 8 trillion Rupiah to slightly lower than 10 trillion Rupiah in 2012, and that the trend is ongoing until current year of 2014 . More specifically, Euromonitor International (2014) also supports the reports that as one of the countries with highest number of Muslims, there are more beauty products launched targeting at Muslim women, with Wardah as the number one competitor followed by Shafira Corporation and several other cosmetics products claiming to be Halal.

Wardah is one of the rising top-leading cosmetics brands in Indonesia. It was first established in 1995 as a home-industry which first initial image was a producing Halal cosmetic for Muslim women (Tajudin et al., 2014, p.43; Wardah Cosmetics, 2011-2014). However, with the existing competitors of imported well-known products such as Maybelline, Revlon and the most established local cosmetic like Sari Ayu Martha Tilaar, Wardah needs to make more efforts gain and sustain the attention of the prospective audience/consumer to develop their loyalty towards Wardah's brand (Sayre \& King, 2010, p.74). According to the survey conducted by the Centre for Middle-Class Consumer Studies (cited in Kurniawan, 2014, p.46) with 1,000 respondents of Middle-Class Consumers in five Metropolitan cities in Indonesia, the priority scale for the Indonesian Middle-Class Muslim Women are the following: 1) Halal, 2) Safe, 3) Ingredients and formula, 4) Registered within BPOM (National
Agency of Food and Drug Control), followed by 5) Rapid results, 6) Affordable, 7) Brand Name Product, and the final two are 8) Peer Recommendation, and 9) Attractive Advertising. It indicates that through the existing Halal label and the printed $B P O M$-registry on their product packaging alone, Wardah has already got high potential in capturing the preferred audience of Indonesian Middle-Class Muslim Women. It is proven by the trend from the same survey that shows $87.5 \%$ of the total respondent of MiddleClass Muslim Women view Wardah as being Halal and thus inferred as trustworthy - a trait that was essential for brand loyalty (Sayre \& King, 2010, p.255).

Just recently, a high grossing Indonesian novel, 99 Cahaya di Langit Eropa (in Australia is translated as Ninety-nine Lights over Europe) was adapted into two-part movies in Indonesia with some screenings in selected countries. The novel and movie adaptation tell about the story of a Muslim Indonesian spouse facing intolerance towards their faith, experiencing exposure from new values which often are in conflict with their religious lifestyle, as well as finding new perspectives towards their faith and belief while the husband was pursuing his Doctoral Degree in Vienna, Austria (Prathivi, 2013, p.12). As one of the leading Halal cosmetics brands in Indonesia, Wardah is chosen by the producers as one of the main sponsors and cosmetics provider for the make-up artists as well as taking charge for the costumes and apparels used for the movies. The reason behind the producers' choice is apparently due to Wardah has already got its own segment of large market - the Indonesian Middle-Class Muslim Women - and that the movie producers also wanted to aim at this prospective group of audience. This is in line with what Grossberg et al. (2006, p. 231) argue that audience can also be seen as a Commodity; where in this case the movie producers deliver this "... audience as a commodity ..." to Wardah in order for the brand to "... get [its] message - 'Consume this product' - to the audience."

As Wardah became the sponsor for the movie adaptation, the brand is entitled to put its products within the scenes of the movie. The products of Wardah Cosmetics are embedded into the plotline of the movie.

By integrating its product in the storyline of the movie and having the product being worn by two of the iconic celebrities in Indonesia, Wardah implements the effort of grabbing the attention of the audience known as captive attention, where the audience cannot willingly evade from the existence of the depicted fashion brand (Davenport \& Beck, 2001, pp.22-23; Sayre \& King, 2010, p.145). As one of the highest grossing movies in Indonesia, 
with a revenue reaching up to USD 1.6 million, it is safe to assume that a quite significant number of audience see and recognize the products being worn by the characters (Sinematek Indonesia, 2014). Both Wardah and the movie producers also made attempt to increase visibility for the selling of the brands and the movies by incorporating the two considerable celebrities in Indonesia to become a role-model (Rojek, 2001) for Indonesian Muslim Women to wear Halal products even when overseas and that a French woman also consume the product.

\section{References:}

Croteau, David, \& Hoynes, William. (2003). Media Society: Industries, Images, and Audiences (3rd ed.). Thousand Oaks: Pine Forge Press.

Davenport, Thomas H., \& Beck, John C. (2001). The Attention Economy: Understanding the New Currency of Business. Boston, Massachusetts: Harvard Business School Press.

Euromonitor International. (2014). Country Report: Beauty and Personal Care in Indonesia. Retrieved September 3, 2014, from http://www.euromonitor.com/beauty-andpersonal-care-in-indonesia/report

Global Business Guide Indonesia. (2014). Indonesia's Cosmetics Market. Global Business Guide Indonesia. Retrieved September 5, 2014, from http://www.gbgindonesia.com/en/manufac turing/article/2014/indonesia_s_cosmetics market.php

Grossberg, Lawrence, Wartella, Ellen, Whitney, D. Charles, \& Wise, J. MacGregor. (2006). Mediamaking: mass media in a popular culture (2nd ed.).

Hodkinson, Paul. (2011). Media, Culture, and Society: an introduction. London: SAGE Publications Ltd.

Kitzinger, Jenny. (2004). Audience and Readership Research. In J. D. H. Downing, D. McQuail, P. Schlesinger \& E. Wartella (Eds.), The SAGE Media Handbook of Media Studies (pp. 167-181). Thousand Oaks: SAGE Publications, Inc.

Kurniawan. (2014, August 3, 2014). The Importance of Halal Products. Tempo English Edition.

Macdonald, Myra. (2003). Exploring Media Discourse. London: Hodder \& Stoughton Educational.
O'Shaughnessy, Michael, \& Stadler, Jane. (2012). Media and Society (5th ed.). South Melbourne: Oxford University Press.

Prathivi, Niken. (2013, December 8 2013). '99 Cahaya' portrays religious suspicion in Europe, The Jakarta Post. Retrieved from http://www.thejakartapost.com/news/2013 /12/08/99-cahaya-portrays-religioussuspicion-europe.html

Rojek, Chris. (2001). Celebrity. London: Reaktion Books Ltd.

Sayre, Shay, \& King, Cynthia. (2010). Entertainment and Society: Influences, Impacts, and Innovations (2nd ed.). New York: Routledge.

Sinematek Indonesia. (2014). 10 Film Indonesia peringkat teratas dalam perolehan jumlah penonton pada tahun 2014 berdasarkan tahun edar film (Top 10 Indonesian Movies in the number of viewers based on the year of distribution). Retrieved September 5, 2014, from filmindonesia.or.id/movie/viewer\#.VAsM IaMxgoo

Tajudin, Qaris, Kurniawan, \& Hidayat, Dodi. (2014, July 28-August 03, 2014). Special Report: Middle-Class Muslims. Tempo English Edition.

Wardah Cosmetics. (2011-2014). Wardah Beauty Concept. Retrieved September 4, 2014, from http://www.wardahbeauty.com/en/about.ht $\underline{\mathrm{ml}}$ 